\title{
(息)
}

Citation:

Barnett, N (2020) Local government and the local trap. Local Government Studies. pp. 1-18. ISSN 0300-3930 DOI: https://doi.org/10.1080/03003930.2020.1761336

Link to Leeds Beckett Repository record:

https://eprints.leedsbeckett.ac.uk/id/eprint/6833/

Document Version:

Article (Accepted Version)

The aim of the Leeds Beckett Repository is to provide open access to our research, as required by funder policies and permitted by publishers and copyright law.

The Leeds Beckett repository holds a wide range of publications, each of which has been checked for copyright and the relevant embargo period has been applied by the Research Services team.

We operate on a standard take-down policy. If you are the author or publisher of an output and you would like it removed from the repository, please contact us and we will investigate on a case-by-case basis.

Each thesis in the repository has been cleared where necessary by the author for third party copyright. If you would like a thesis to be removed from the repository or believe there is an issue with copyright, please contact us on openaccess@leedsbeckett.ac.uk and we will investigate on a case-by-case basis. 


\section{English Local Government and the Local Trap}

\section{$\underline{\text { Abstract }}$}

Local government in England faces unprecedented challenges, with ten years of austerity adding to concerns over its waning influence. Responses so far have involved dismissing local government for more radical alternatives or the re-iteration of increasingly shaky defences. The paper argues that resetting the debate around local government's place in the polity requires starting with meanings assigned to the local, which are at present constrained by the 'Local Trap', and that looking at the English case gives an insightful view of its consequences. I identify three ways in which local government discourse is trapped; by assumptions about the 'naturalness' of the local; assumptions about its democratic qualities; and an adherence to scaler representations. I argue that as a consequence, attention has been diverted to either local government past or an elusive one to come, before setting out potential pathways out of the trap in the form of more robust engagement with practice.

Local government in advanced capitalist economies faces unprecedented challenges. Austerity governance has added to existing concerns over its democratic credentials and waning influence amidst the networks of the local governance environment. These have been prominent particularly in England, adding here to an existing discourse of weak local government and making it increasingly difficult to make a case for local government in a way which responds adequately to this austere and fragmented reality. Subsequently, local government has been either dismissed for more radical alternatives, or defended by re-iterating what seem to be increasingly shaky underpinning concepts. Even an emergent 'New 
Municipalism' has been ambivalent about local government. This paper uses the English experience to make the central argument that defending local government requires a robust engagement with what should be an obvious starting point -the local. Indeed, I argue that discourse around local government has been 'trapped' in taken for granted assumptions around the virtuous nature of the 'local', leading to the re-iteration of arguments which fail to resonate sufficiently with practice. Without confronting and problematising the local, we will continue to repeat these failings, and be unable to make the necessary move towards a more grounded, pragmatic approach which identifies local government as a material component of the local.

Using the case of English local government, this paper seeks to address this deficit. Discourse around local government in the United Kingdom has long lamented its large scale and centralised nature and has been rife with calls for it to be more genuinely 'local'. This has remained the case, with some divergencies emerging as a result of devolution to Scotland and Wales in 1998, and changing degrees of self-rule in Northern Ireland, which have, in effect created four local government systems. In England, 'localism' has been used by governments as a constant referent across several decades as a solution to a variety of economic and social problems (Brownill, 2017). This was intensified in the 'localism' agenda after 2010 and consolidated in the Localism Act of 2011. This agenda has often by-passed local government in favour of civil society, whilst at the same time its legitimacy has been challenged by declining public interest, the promotion of alternative forms of democratic engagement, and loss of direct service delivery of key services, with even local government advocates beginning to argue for its lack of future relevance (Lent and Studdert, 2019). Ten years of austerity have added to these pressures. Further, new sub-regional Combined Authorities and even larger unitary councils have been created via mergers based on contended imaginaries of 'the local', leading to a 'doubling down' on calls for more 'local' solutions. English local government, 
then, provides a rich source from which to draw out the contested meanings and practices of the 'local'.

The argument unfolds in three steps. First, I identify the shortcomings of current defences of local government, by building on Purcell's (2004) metaphor of the 'Local Trap'. Purcell critiques discourse around 'The Right to the City' as relying on essentialist conceptions of the local and being 'trapped' by assumptions about qualities attached to social scales. Applying this to discourse around local government in England, I identify three ways in which the debate has been 'trapped'. These are assumptions about the 'naturalness' of the local; assumptions about its inherent democratic qualities; and adherence to scaler representations and the 'othering' of the centre. The second step critically assess the consequences of this trap in constraining discourse around local government. Here I argue that being in the trap limits attention to either local government past or an elusive one to come, with the tools used being too blunt to treat local government present as anything other than something to be escaped. Put alternatively, these assumptions about the nature, positive qualities and values inherent in the 'local' either lead, I argue, to a dismissal of local government, or leave advocacy for it firmly attached to essentialist notions of the local. Finally, in conclusion, I propose a number of tentative pathways out of the trap, which seek to ground the local in ways which enable us to imagine a local government which 'grips'. More specifically, I point to the value, across different contexts and systems, of adopting a pragmatist stance focussing on local government as it exists.

\section{The Local Trap}

Purcell's 'Local Trap' draws on social constructivist critiques which undermine a priori claims for the qualities of scales of organisation or engagement, to argue that 'scale is not an 
ontological entity with particular properties, it is better seen,.........., as a strategy, as a way to achieve a particular end' (Purcell, 2004, 1924). The local here is not conflated with 'democratic', nor with 'community' or a natural source of sovereignty. In contrast, 'localising can produce greater democracy or not, or greater social justice or not, depending on who is empowered by the localisation. And there is no inherent or even tendential link between the agendas of local scale groups and the agenda of democracy or that of social justice. The same is true of regional-scale groups, or national-scale ones' (1927).

Being trapped entails failing to recognise the local, or any other scale, as a relational concept, constructed via social and political contestation. A focus on fixity has led us to 'treat scale as a latent variable instead of an active object of inquiry' (1927). Scales can, of course, achieve fixity or 'structured coherence'; 'However, even if scalar assumptions tend to be valid in a particular case, they will never be always valid.... such structured coherence is always temporary' (1928). Purcell and others (for example, Thrift, 2004) thus warn against making assumptions about types of politics inherent in any scale or location, focussing instead on 'how the interrelationships among scales are continually fixed, struggled over and reworked by particular social actors pursuing specific political, social, economic and ecological goals' (1929).

I focus below on three key, inter-related, ways in which narratives around local government have been trapped and insufficiently engaged with these relational and practice-based perspectives. Failure to engage with these contested meanings restricts our ability to set local government in the context of encroaching critiques, where the local is 'poached' by understandings which do not necessarily see a role for local government, as critical attention turns to the neighbourhood, the 'everyday', the urban, or new state scales including the subregion, leaving local government vulnerable. I do not argue that all discourse around local government has relied on a unified vision of the local; these have been extrapolated from a 
range of sources, liberal, conservative and socialist, and have covered both expediential/ efficiency-based and normative/ ethical underpinnings (Jones and Stewart, 2012). However, they share a belief in the local, variously defined, being imbued with particular qualities. This has led to an inevitably frustrating attempt to pin down the local, to arrive at 'best fit' compromises which trade off one definition of the local with another..

\section{$\underline{\text { The natural, 'localism lost' trap }}$}

A vision of the local as an end in itself, bearer of moral characteristics, something lost, the subject of aspiration, to be returned to, has been a persistent undercurrent in discourse around local government, in references to natural, or organic localities. Here, the local is normatively defended variously as the primary source of emotional attachment, autonomy, self-organisation and practical knowledge, as exemplified in the work of Toulmin Smith and De Tocqueville (Chandler, 2008). Other varieties of 'romantic' localism draw from radical to conservative traditions (Grant and Dollery, 2011). Conservative thought imbues the local with inherent qualities from a range of justifications, from the 'little platoons' of Burke, the local knowledge foregrounded by Oakeshott, or the more libertarian, allocative efficiency- based arguments of new right and public choice theorists. Echoes of all of these can be found in the 'localism' agenda and the Localism Act of 2011, with its aim of devolving power to community groups, and the associated 'Big Society' initiative, based on 'a middle ground between long-standing and rival conservative traditions of libertarianism (e.g., free markets, localism) and paternalism (e.g., community and social stability)' (Buser, 2013 7). Socialist thought has traditions of local self-government stemming from GDH Cole and Robert Owen, a thread now rediscovered in current 'new municipalist' interest in 'Libertarian Municipalism' (Bookchin, 1991). Again, this canon spans a wide range, with, for example, Fabians and Harold Laski at various times advocating neighbourhood whilst warning of the dangers of parochialism. 
Re-articulating such established appeals, Copus (2019), for example, points to an inherent localness in English history and common law which has been usurped systematically since the time of the Norman invasion. 'Local' government is here associated with an organic, unhindered, self-governing Anglo-Saxon settlement, or is grounded in forms of sovereignty which pre-date the nation state and which remain just as, if not more, normatively valid (Magnussen, 2005). The local which has been lost, however, varies in form and time period, ranging from the ancient folk moot, to the Parish, to the local government units of the nineteenth century. Similarly, differing turning points in its loss are offered; beyond the Norman invasion, the Poor Law Amendment Act of 1832 is perhaps recognised as the most significant event in the usurping of natural localities, here seen to be represented by the pre1832 parishes. Alternatively, the local is found in nineteenth century local government, equating here with municipality or town, and a form of 'real' local government which Wills (2016) argues 'never got a real chance' in the UK.

Belief in the intrinsic value of the local has led to imprecise appeals to localities with geographic integrity, and to local government being vaguely defined as, for example, 'the government of local communities' (Jones and Stewart, 2012), leaving unanswered what these communities are, or how they come about. For Copus, Roberts and Wall (2017), the local is self-defined; local people decide (somewhat tautologically) what is local, and boundaries emerge from the bottom up. They advocate for a new narrative of 'Muscular Localism', a vison of local government based on governing rights for 'geographically identifiable' communities. Similarly, Copus (2006) refers to 'identifiable and definable communities', which have 'a cohesive and clear view of [their] identity in a geographical sense' (p.18), while Copus, Sweeting and Wingfield $(2013,397)$ underline the 'spatial aspect of local democracy', leaving open once again the question of what these spaces may be. Chandler (2008) stresses that differing and changing spatial geographies of shared interests can be accomodated via a range 
of sizes and tiers of local government, but also relies on self-identification as the basis for the construction of these various 'locals'.

\section{The local as inherently democratic}

Within the 'trapped' mindset, the organic nature of the local is closely related to its perceived democratic qualities, with increasing size of local governments associated with declining democracy. Normative support is derived from a range of philosophical positions, with varieties of liberal democratic theory providing the main grounding, embracing combinations of liberty, participation and efficiency, and suggesting that democracy has to have a local dimension. The democratic contributions of the local here are various- as a stage for participation, protecting individual interests whilst also providing civic responsibility and education; as a counterweight to a potentially autocratic centre, ensuring a plural dispersal of power; and allowing an accessible platform for group participation and resolution of conflict (Sharpe, 1970; Wolman, 1996). Chandler (2008) anchors these democratic qualities in libertarian grounds, drawing on JS Mill to develop an understanding of moral autonomy linking the freedom of the individual with its necessary enactment via free association with those who have shared interests. Beetham (1996) revisited liberal democratic values to provide a normative defence for local government based on the intrinsically democratic qualities of the local, stemming from the dual principles of political equality and popular control, seeing the local arena as the best for securing the associated principles of accountability, responsiveness and representativeness. There is within these defences a privileging of this kind of normative liberalism in contrast to the utilitarian liberalism of Bentham, for example, which identified local democracy with the potential to subvert democracy, in its majoritarian form, via the promotion of particular interests. The trap ensures that this is largely downplayed, but democratic qualities have also been attributed to the local on broadly utilitarian grounds, for example in Sharpe's (1970) classic defence of local government based on its capacity to 
efficiently deliver outcome democracy, by ensuring nationally determined priorities were as far as possible congruent with local circumstances. Thus, liberal views of local government's democratic qualities are based on protection of shared interests ( for example, Chandler, drawing on Mill), or more on grounds of the accurate (and therefore efficient) matching of

service delivery with local needs (the case classically put by Sharpe), with traces of both being found in later twentieth- century liberal defences provided by TH Green and the Fabians. Overall, as Wills (2016) notes, the 'local', as 'spatial liberalism', has been deployed to address the contradictions at the centre of the 'liberal dilemma' of both promoting and constraining individual freedom in a democratic fashion.

\section{The local and the othering of the 'non-local'}

Finally, the organic and democratic qualities of the local are coupled with the 'othering' of alternative scales, primarily the centre, which is seen as its binary opposite. The trap here manifests itself in an essentialising of scale, with the local in a dichotomous relationship in which power is seen (in what John, (2014) has labelled the 'declinist' narrative amongst local government scholars in the UK) to be lost in an inexorably in one direction. The 'centre' thus appears as a unified whole in a zero-sum game, remote both in geographical distance (meaning that local wishes cannot be known there) and in power imbalance. This centralisation is then insensitive to clearly defined local characteristics and preferences (Jones and Stewart, 2012) which are ironed out, whilst alternative, historically relevant forms of sovereignty and attachment are subsumed. Depending on which 'local' is being imagined, it is also contrasted with other scales, including artificially created local government units; for example, large unitary councils, Combined Authorities, and 'points of the compass' authorities created for bureaucratic convenience (Copus, Roberts and Wall, 2017). Here, the role of 'local' lobbies and interests in creating these structures is not explicitly, usually, examined. 
It is true that there has been in the field been a long-standing recognition of the need to balance universal and local concerns, or to 'trade off' some localness for other values, including efficiency and effectiveness, such that certain issues have to be dealt with at a variety of scales. Indeed, the 'small is beautiful' rhetoric has by no means been the only one evident; it was common at one time, amongst local government commentators- notably WA Robson- to argue for larger local authorities, on the basis that they would be more of a protection against the centre, more capable of being understood by the populace, of providing major welfare services, and of having more strength in negotiations with central government. However, the characteristics of the trap are related here more to a mindset which essentialises scales, and views them as dichotomously and hierarchically structured.

Thus, despite years of debate and research into attachments and affinities relating to local government in which pinning down the local has proven elusive, there is continuing belief in its objective reality in unified and cohesive entities, and this continues to be pervasive. The recent revived interest in 'new municipalism', for example, is based on either the municipality, thus identifying with an image of nineteenth century 'strong' and more independent local governments, or the urban, as a distinct spatial scale with inherent democratic qualities. Thus, what Cochrane calls the 'strange dance of the local' $(2016,908)$ continues.

\section{The trap's consequences}

The consequences of the 'trap' further expose local government as it faces existential threats, and lead to the side-lining of local government in debates surrounding possible progressive/ alternative futures. It leads to continued attempts to secure trade-offs to achieve optimum democratic outcomes, serving to limit richer consideration of the local as a political arena, whilst, ironically, also side-lining insights which are already present in the local government canon. Finally, via 'othering' and by essentialising scales, it leads to a failure to engage with 
more relational understandings of scale, missing opportunities for a richer understanding of the practices involved in the creation and maintenance of local government structures.

Firstly, ten years of austerity have brought to the fore alternative imaginaries of the local and pose questions concerning local government's relationship to them. As 'austerity localism' (Featherstone et. al, 2012) the local has been associated with technologies of control and coercion (Brownill, 2017), or, as casting a 'post-political' veneer of consensus over on-going cuts and state restructuring (Clarke and Cochrane, 2013). Local government is dismissed as at worst repressive, tainted by 'austerian realism' (Davies and Thompson, 2016), and at best as representing state paternalism. The local has also been commandeered to legitimate the government's devolution agenda, constructing localisms around new strategic bodies, including Combined Authorities and other sub-regional initiatives, and used variously to refer to City Regions, Functional Economic Areas and new 'fuzzy spaces' created to link together projects and bids for funds (Cochrane, XXXX). All of these imaginaries make claims to the local which have consequences for local government, making clinging to essentialist notions an increasingly inadequate response.

Even when responses have sought to invest in the local as site of resistance, hope, and progressive alternatives, the trap is repeated by the privileging of the local by those who, emphasise agency operating in the 'gaps cracks and fissures' of the localism agenda and 'actually existing' austerity, (Williams, Goodwin and Cloke, 2014). Also, progressive political and economic models based around Community Wealth Building, or local inclusive growth and democratic ownership (O’Neil and Howard, 2018; McInroy, 2108) have brought alternative views of a progressive municipal local government to the fore, but continue to view this, municipal, local as being imbued with these potentials for resistance, progressive outcomes and radical democracy. Others find hope in the local but are at best sceptical about local government's relationship to it. Russell (2019), for example, draws on Lefebvre's 'Right 
to the City' to stress the politically generative qualities of proximity to be found in the urban, seeing therein an inherent, prefigurative, radical potential, now to be found in autogestion and self-organisation. For Russell, local government is of interest in so far as it is a site within/ against which agents act and is as likely to be identified as a problem rather than a solution, even when some Councils- notably Preston City Council- have received plaudits for leading progressive alternatives. These alternatives then, stress differing 'locals' but continue to see them as being imbued with inherent qualities.

Secondly, in maintaining the view that the local provides a solution to tensions in democratic practice, the 'trap' ensures continued attempts to secure trade-offs to achieve optimum democratic outcomes, and so ensures that local government discourse fails to fully address fundamental issues raised in classic arguments from the canon. Democracy is an essentially contested concept, and the local government literature itself contains explicit recognition of this, in long-standing debates about the tensions between local diversity and universal provision; between 'direct' and representative democracy; and about whether small- scale political units are more likely to be bulwarks of freedom or enclaves of exclusion and prejudice- as evidenced in the classic interchange between Professors Langrod and PanterBrick in Public Administration (Panter-Brick, 1954). There is also a long-standing recognition that democracy requires both participation and functional effectiveness, that democracy can operate at a number of scales, that 'local' decisions mean nothing unless they can be operationalised (Newton, 1982), and that larger local governments may be more plural, diverse, and democratic. However, considerations of the role and purpose of local government in the field, (which has, admittedly, become relatively narrow), have usually lamented, for example, effectiveness arguments leading to increasing sizes of local councils, as, a priori, reducing 
democracy. In turn, the association of democracy with the 'natural' local, leads to a desire to 'push downwards' to 'lower' scales, in a search to locate it.

This is not to say that developments in democratic theory have not been considered, as prompted by a growing 'democratic deficit'. In particular, the possible incongruities between elected, representative democracy and other forms, notably participative and deliberative, have been reviewed through a local lens (Sweeting and Copus, 2012). Democratic deficits created by the move to networked governance have been addressed via 'Second Generation' governance theory which attempts to locally 'anchor' these, democratically, via 'metagovernor' roles Copus (2016). Ideas concerning the democratic qualities of the local have been moved on by drawing on deliberative and communicative principles (Newman, 2014), which deploy the all-affected principle to 'make up' the local. However, such approaches generally downplay the constitutive role of conflict in politics and lead back to a romantic, consensual local, (Barnett, Griggs and Howarth, 2019), leaving open issues of how the 'local' demos is constructed, whose interests are affected in a plethora of policy areas, and the issue of the boundary of the local and what is excluded from it. In this way, these more 'communicative' defences of the local lead partly out of the trap, only to return to it.

The trap thus also leads to the limiting of consideration of the local as a political arena and failure to consider the consequences for local government of a more 'horizontal', 'non-linear', local politics, unbounded from liberal democratic limits (Chandler, 2014). This highlights the continuous contestability of institutions, boundaries, and of the issues that shape the 'local' public realm. However, of course, issues do 'touch down' and are experienced in lived space, and political agency is created in 'situated places of transactional intensity' (Barnett and Bridge 2013, 1036). Local politics will influence and be influenced by material places (Leitner et. al 2008) and questions are posed about the interplay between fixity and fluidity, the overlapping spatialities of issues of concern, and the institutions necessary for collective decision-making. 
In other words- we are led back in the direction of local government in some form, but a consequence of the trap is that these avenues are not explored. This would not require the wholesale ditching of theories of democracy which have populated local government studiesincluding the value of plurality of decision-making and checks and balances against the possibility of overbearing authority. However, the trap leads to their continued predominance at the expense of building a narrative around local government which acknowledges fully the challenges of 'post liberal' democracy.

Lastly, the 'othering' and scaler assumptions of the trap contrast with a more relational understanding which identifies scales as 'multiple, overlapping, tangled, interpenetrating', with actors 'reaching' from, into, and across them (Allen and Cochrane, 2010, 1077). Staying in the trap thus leads to circular arguments, perpetuating the elusive search for the local, negotiating how much of it may be traded off, searching for concentric tiers which match and demarcate various definitions of it, and thus further displacing the local into the past (now lost) or futurethe 'real' local which we would create if given chance- the local to come.

Leading from this, further consequences emanate from a lack of focus on the practices, assemblages, and processes by which the local is constructed. Over concentration on the dominance of the centre leads to a failure to engage with wider considerations of state and scaler restructuring, an area largely occupied by political geographers and regional and urban scholars who have focused relatively little attention on local government per se, leading to insufficient consideration of the processes- the how and why of particular scales are constructed as local governments, and why they persist or not. As noted, the 'relational turn' points towards the 'politics of scale', the interplay of fixity and flow, how 'state spaces' are created/re-created by the territorial reorganisation of boundaries and local agency responsibilities, and their effects on access to power. Here, interest turns to the meanings and purposes assigned to, and the way in which various actors use, 'local' structures, how they become 'spatial imaginaries', 
how geographies are mobilised and politically contested, and to the essentially political act of boundary making; in short, how the local is made and re-made in practice (Boudreau, 2007, Pemberton and Goodwin, 2010).

Mainstream local government discourse has thus largely avoided the 'critical junking' (Cochrane, 2016) of the local and an appreciation of it as a 'fuzzy' concept- malleable, contentious and elusive, always porous and 'straining at the limits' of local government (Clarke and Cochrane, 2013; Cochrane, 2015). Of course, the meat and drink of discourse around local government reorganisations, or boundary changes, has recognised exactly these points- that overlapping interests/ affinities criss-cross any territorially-bound solutions. Being in the local trap, however, means that even the recognition of this leaves to a continued chase for a settlement, a fixity, whether an 'ideal' form or a trade-off, something which is always over the horizon.

The argument here is not that we should 'throw the baby out with the bath water' nor set up an 'old' versus 'new' dichotomy, with various 'critical' insights somehow being superior. The consequences outlined above contain indications of possible pathways forward; indeed, to an extent these overlay traces of established rights of way which have been under-used. Free from the trap, the local government canon offers much to the necessary debates, via the 'reining in' and grounding of relational theory. Local government re-organisations, for example, can reveal much about competing interests in the construction of scales, but have been under-utilised in this respect. A further consequence is that local government scholars, aside from a few notable exceptions (for example, Cochrane and Wills) have been absent from these debates; thus, the chance to revisit, revise and adapt more 'traditional' defences has been missed. Local government has been rooted in theories and concepts which continue to find resonance in the developing literature on the local, which itself often has blind spots with regard to institutional fixity and collective decision-making. However, escaping the trap, I would argue, is a 
prerequisite to 'retooling' defences and contributing to the search for a local government which resonates with lived experience. Below I briefly set out three possible escape routes; via engaging with the 'geographical turn' in democratic thought and with the processes by which the local is institutionally grounded and affectively imagined; via engaging with the processes by which 'local' scales are assembled and re-assembled, and via engaging with blindspots in radical democratic theory and the 'politics of proximity'.

\section{Escaping the trap?}

A way out of the trap is not to dismiss the local either as a given or as endlessly elusive, but to engage with it from starting points which have more 'grip', recognising the interrelationship of local government and the local. There are several ways in which this 'retools' and brings back in ideas concerning the relevance of local government in ways which are more fit for purpose. On the one hand, a more materially grounded approach brings back into the equation historicity and path dependency in the form of prior institutional and political configurations (Mackinnon and Shaw, 2010). On the other hand, a 'politics of affect' applies some 'geographical anchors' (Jones, 2009) to relationality, foregrounding more the emotional attachments of lived space, re-emphasising dwelling and temporal depth (Tomaney, 2012) which 'gets under the skin' (Dicek, 2005). Thus, the 'lure' of the local persists; spatial concepts provide 'sureity' and solace for local agents and political activism (Jones, Mann, Heley, 2013; Chatterton, 2010). In other words, local governments are concrete, material spaces in/ on which the situated practices of agents are played out, but also form meaningful geographies for their populations and agents which shape, and are shaped by, those practices. This understanding helps to avoid taken for granted assumptions about the local whilst also challenging its elusiveness. 
Exploring such avenues of enquiry opens up a strengthened engagement with the 'geographical turn' in democratic thought (Barnett, 2014, 6) which has 'led back' relational geography towards an 'institutional imagination' (Barnett and Bridge, 2013, 1024), moving beyond the binaries of scaler essentialism and 'mundane' practices (or 'flat relationality'). Here, there is a recognition of the 'structural push' which fragmented political mobilisations require (Nicholls, 2008), and the need for a scale/ platform on which politics can be performed and change visualised. Institutions do, of course, matter; discrete, bounded scales act as political 'imaginaries', given temporal depth by historically patterned practices, and as stages for practical politics (Moore 2008). Institutions, together with the 'collections of signs, symbols, [and] practices....that coalesce around a given point' are important in making up the assemblages which give meanings to place (Willett, 2016, 441), and Fuller (2012) notes how such assemblages are reterritorialized and given fixity by 'spatial imaginations' which derive from institutional boundaries. These lines of enquiry re-surface local government in the local, as a bounded institution with temporal depth. However, they do not trap us; they tell us that fixity in turn generates its own contestation, opening up lines of enquiry not around ideal locals but around the essential contestability of its form and nature.

Escaping the trap thus requires more consideration of the politics of how local governments as places are constructed/assembled; how, where and why meaning, spatial imaginary and resonance (Willett, 2016) are attached to them, and in turn how local government contributes to those resonances, and in what ways. We know that local governments can produce symbolic and cultural attachment, providing a focus for the practical 'doing' of politics; Town Halls, for example, act as symbols around which to rally, figuratively and literally. Does this 'grip' change over time and move, territorially, and to what extent do local government boundaries effect this? Why and how do Councils have 'grip'? Which 'artificial' councils seem to embed and gain traction as imaginaries and which do not, and why? The county of Humberside, for 
example, created in 1974 as an amalgam of parts of Yorkshire and Lincolnshire was still portrayed, almost thirty-five years later, as 'the County which no one loved' (Yorkshire Post, 2008) and yet research prior to its abolition in 1996 showed positive identification with it amongst younger residents.

Release from the 'scaler mentality' will also refresh a recognition of the 'reach' of local government actors into other scales, of the influence local government is actually having in Whitehall and at other locations, of which local lobbies have more influence, and how this may change over time. Also, it can facilitate a greater recognition of local government's role in the on-going layering and state scale restructuring which until now has tended to be ignored or downplayed, for example, in the debates about City-Region and Combined Authority creation, even though local governments have been key players in either facilitating or blocking such moves (for an exception, see Pemberton, 2016).

Importantly, leaving the trap moves beyond embedded dialogues of liberalism to engage with challenges from post-liberal and post-representative politics, which themselves have difficulty moving from critique to governance and decision-making, leaving an institutional gap (Howarth, 2008, Lowndes and Paxton, 2018) and a potential 'tyranny of structurelessness'. They risk falling themselves into the 'purity politics' trap of assuming that 'autonomous' local groups will necessarily pursue progressive ends (Bruzzone, 2019) and can direct too little attention to the embedded geographies where politics most obviously takes place (Barnett and Low, 2004), for example in local elected councils. Thus, Wills (2013) has drawn on Massey's distinction to argue that too much attention has been paid to the politics of place, at the expense of the more 'obvious' politics in place. Councils provide a focus for the practical 'doing' of politics and, in the political 'imaginary', elected Councillors have a 'head start' over others in terms of perceived legitimacy (Judge 2013). 
Recognising the limitations of the trap will allow this blindspot to be addressed, informed by the exploration of what local government experience, for example from the New Urban Left Councils of the 1980 's, can tell us about radical aspirations and the practice of institutional power holding. To what extent can local governments in practice, have prefigurative, progressive potentials (Cooper, 2017) and foster them over other than short periods of time? Can it be a 'dual intermediary', in this sense? (Barnett, 2011).

In addition, whilst there is nothing essentially democratic about proximity, release from the trap allows us to envisage some revised foundations for local government based on a 'politics of responsibility' (Escobar, 2013) to care for others with whom we share proximity and experiences (Frazer, 1996; Sullivan, 2011). Thus, Sullivan argues that proximity underpins a 'logic of care', offering a safety net to the vulnerable and acting as a springboard for innovative practice. Newman (2014) similarly draws on 'inherent need', based on universal basic needs and social justice, to produce an ethical framework as a guide for progressive local government.

This grounded approach offers potential pathways out of trap. These could include, for example, taking 'geographies of care' as a starting point. Also, a more nuanced appreciation of the 'politics of affect', the generative aspects of place, and the 'complex multidirectional netting' (Seamon, 2014, p.16) of belonging would move us beyond trying to delineate boundaries towards understanding the 'affective assemblies' which lead to more or less attachment to local government areas, and how these attachments affect practices or are influenced by material policy interventions aimed, for example, at civic culture and engagement. Other paths take us via the 'relational turn' towards considering local governments as material entities, with institutional and historical grounding and influence, which give fixity to flow, on to lines of enquiry into the consequences of relationality for the practices of 'local' politics, representation and participation (Pugh, 2009) and further on to how 
the institutional contexts of local governments influence a 'relational' politics of multi-scaler connections (Darling, 2009).

\section{Conclusion}

This article has argued that being in the local trap is restricting moves towards any new justificatory narrative with which local government needs to be informed at a time when it faces acute threats it is being buffeted from all sides of the political spectrum. These threats are enhanced by undermining of some of the cherished foundations on which traditional defences have been built, from across a range of academic disciplines. The three main aspects of the trap have been set out, their consequences, and potential escape routes. The fundamental pillars of the local trap continue to constrain discourse concerning local government's future. The two options currently in circulation in the English context as the best hopes for meeting current challenges are 'Muscular Localism' or the 'new municipalist' movement. However, these both remain trapped, one resting on natural, self-identifying communities, the other valorising proximity, and, in some cases, being informed by a 'state phobia' which sees local government as more a problem than a solution.

The English case has been used here, but I would argue that questions concerning the extent of the 'grip' of the trap are relevant more broadly. Other countries may have stronger defences of local government to draw on, none the least constitutional protections which are absent in England, but they are still subject to encroaching critiques around scale and democratic practice. Across all contexts, it is only through stepping beyond the confines of established thinking on the local, and the reframing of the debate around it, that robust, relevant defences of local government which 'grip' with actual lived experience will emerge from such challenges. Similar questions are posed concerning meanings of the local, for example, across countries, by the growing, international 'new municipalist' and 'Fearless Cities' movement. 
Internationally, local government studies needs to engage more fully with contested meanings of the local, address more directly the challenges arising largely from outside of the academic field, and consider the extent to which traditional defences need to be or can be 're-tooled'. 'Local' is, after all, $50 \%$ of the signifier of local government, but for the large part, debate around it does not 'do what it says on the tin'. Indeed, staying in the local trap means advocating for local government based on articles of faith rather than through robust engagement.

An escape from the trap could start with a more explicit foregrounding/ remembering of tools which are already to hand which point to the tensions and paradoxes involved in making a case for local government. These must be sharpened by critical engagement with, in particular, relational and non-essentialist understandings of the local. This, leads, in turn, onto engagement with the 'logic of the local'- 'the amalgam of rules, norms and processes that constitute regimes of practice' (Blanco, Griggs and Sullivan, 2014, p.3131), to how these become stabilised or challenged, and when and why local governments are used as 'spatial tools' in these processes. This means challenging outdated logics, adopting a pragmatist stance focussing on local government as it exists, as an institutionalised, material site which matters as a site of resonance, performativity, engagement and agency. In turn, this obliges us to start from where we are rather than with normative or ideological narratives concerning 'ideal' local governments, and beginning with what we have, or with things as they pass (Massey, 2013). Seeing local government in and through the institutions, rules and norms that compose the logics of the local will give us more of a solid foundation for local government based on practice. This requires advocates for local government to start at different points, with open lines of enquiry, taking the local as a category of practice rather than analysis.

\section{References}


Allen, J., and A. Cochrane. 2010. "Assemblages of State Power: Topological Shifts in the Organization of Government and Politics". Antipode 42 (5): 1071-1089.

Barnett, C. 2014. "What Do Cities Have to Do with Democracy?" International Journal of Urban and Regional Research 38 (5): 1625-1643.

Barnett, Clive, and Murray Low. 2004. “Geography and Democracy: An Introduction”. In Spaces of Democracy, edited by Clive Barnett and Murray Low, 1-22. London: Sage.

Barnett, C., and C. Bridge. 2013. "Geographies of Radical Democracy: Agonistic pragmatism and the formation of affected interests". Annals of the Association of American Geographers 103 (4): 1022-1040.

Barnett, N. 2011. "Local Government at the Nexus". Local Government Studies 37 (3): 275290.

Barnett, N., S. Griggs and D. Howarth. 2019. "Whatever Happened to Councillors?: Problematising the Deficiency Narrative in English Local Politics”. Political Studies 67 (3): 775-794.

Beetham, David. 1996. "Theorising democracy and local government”. In Rethinking Local Democracy, edited by Gerry Stoker and Desmond King, 28-49. London: MacMillan.

Blanco, I., Griggs, Steven and Sullivan, Helen. 2014. "Situating the local in the neoliberalisation and transformation of urban governance". Urban Studies 51 (15): 3129-3146.

Bookchin, M. 1991. "Libertarian Municipalism: An Overview”.

https://theanarchistlibrary.org/library/murray-bookchin-libertarian-municipalism-an-overview 
Boudreau, J-A. 2007. "Making New Political Spaces: Mobilizing Spatial Imaginaries, Instrumentalising Spatial Practices, and Strategically Using Spatial Tools”. Environment and Planning A: Economy and Space 39 (11): 2593-2611.

Brownill, S. 2017. “Assembling Neighbourhoods: Topologies of power and the reshaping of planning". In Localism and Neighbourhood Planning: Power to the people?, edited by Sue Brownill and Quintin Bradley, 145-161. Bristol: Policy Press.

Bruzzone, V. 2019. “The Moral Limits of Autonomous Democracy for Planning Theory: A Critique of Purcell”. Planning Theory 18 (1): 82-99

Buser, M. 2013. "Tracing the Democratic Narrative: Big Society, Localism and Civic Engagement”. Local Government Studies 39 (1): 3-21.

Chandler, D. 2014. "Democracy Unbound? Non-linear Politics and the Politicization of Everyday Life". European Journal of Social Theory 17 (1): 42-59.

Chandler, J. 2008. "Liberal Justifications for Local Government in Britain: The Triumph of Expediency over Ethics”. Political Studies 56 (2): 355-373.

Chatterton, P. 2010. "The Urban Impossible: A Eulogy for the Unfinished City”. City 14: 234244

Clarke, N. and Cochrane, Alan. 2013. "Geographies and politics of localism: the localism of the United Kingdom's coalition government political geography”. Political Geography 34: $10-23$. 
Cochrane, A. 2015. 'So, how come local government is still around after all these years?' in 'Whatever happened to local government? A review symposium'. Regional Studies, Regional Science 2 (1): 435-457.

Cochrane, A. 2016. "Thinking about the 'Local' of Local Government: A Brief History of Invention and Reinvention”. Local Government Studies 42 (6):907-915.

Cochrane, A. 2019. "In and beyond local government: making up new spaces of governance". Local Government Studies DOI: 10.1080/03003930.2019.1644321

Cooper, D. 2017. "Prefiguring the State". Antipode 49 (2):335-356.

Copus, C. 2006. "British Local Government: A Case for a New Constitutional Settlement". Public Policy and Administration. 21 (2): 4-21

Copus, C., D. Sweeting and M. Wingfield. 2013. "Repoliticising and redemocratising local democracy and the public realm: why we need councillors and councils". Policy \& Politics. 43 (3): 389-408 2013.

Copus, Colin. 2016. In Defence of Councillors. Manchester: Manchester University Press.

Copus, Colin, Mark Roberts and Rachel Wall. 2017. Local Government in England: Centralisation, Autonomy and Control. Basingstoke: Palgrave MacMillan.

Copus, Colin. 2019. “Englishness and Local Government”. In These Englands: A Conversation on National Identity, edited by Arthur Augey and Christine Berberich. Manchester: Manchester University Press.

Darling, J. 2010. "A city of sanctuary: the relational re-imagining of Sheffield's asylum politics”. Transactions of the Institute of Political Geographers. 35 (1): 125-140 
Davies, Jonathan and Edward Thompson. 2016. "Austerity Realism and the Governance of Leicester". In Rethinking Governance: ruling, rationalities and resistance, edited by Bevir, Mark, and Rod Rhodes, 144-161. Oxon: Routledge.

Dikec, M. 2005. “Space, Politics and the Political. Environment and Planning D. 23 (2): 171188.

Escobar, A. 2013. "Relational Ontologies and Geographies of Responsibility". In Spatial Politics: For Doreen Massey, edited by Featherstone, David. and Joe Painter, 168-171. Chichester: Wiley-Blackwell).

Featherstone, D., A. Ince, D. MacKinnon, A. Strauss, and A. Cumbers. 2012. "Progressive localism and the construction of political alternatives". Transactions of the Institute of British Geographers. 37: 177-182.

Frazer, E. 1996. “The Value of Locality”. In Rethinking Local Democracy, edited by King, Desmond, and Gerry Stoker, G., 89-110. London: MacMillan. 89-

Fuller, C. 2012. "Urban politics and the social practices of critique and justification: Conceptual insights from French pragmatism". Progress in Human Geography. 37 (5):639657.

Grant, B, and B. Dollery. 2011. "Political Geography as Public Policy? 'Place-shaping' as a Mode of Local Government Reform". Ethics, Policy and Environment. 14 (2): 193-209. 
Howarth, D. R. 2008. "Ethos, Agonism and Populism: William Connolly and the Case for Radical Democracy”. The British Journal of Politics \& International Relations. 10 (2): 171193.

Jones, G., and J. Stewart. 2012. "Local government: The Past, the Present and the Future". Public Policy and Administration. 27 (4): 346-367.

Jones, L., R. Mann, and J. Heley. 2013. "Doing space relationally: Exploring the meaningful geographies of local government in Wales”. Goodrum. 45: 190-200.

Jones, M. 2009. "Phase space: geography, relational thinking, and beyond". Progress in Human Geography. 33 (4): 487-506.

John, P. 2014. "The Great Survivor: The Persistence and Resilience of English Local Government”. Local Government Studies. 40 (5): 687-704.

Judge, D. 2013. "Word from the street: When non-electoral representative claims meet Electoral representation in the United Kingdom”. British Politics. 8: 338-409.

Leitner, H., E. Sheppard, and K.M. Sziarto. 2008. "The spatialities of contentious politics". Transactions of the Institute of British Geographers. 33 (2): 157-172.

Lent, A. and J.Studdert. 2019. The Community Paradigm. NGLN. 
Lowndes, V., and M. Paxton. 2018. "Can agonism be institutionalised? Can institutions be agonised? Prospects for democratic design". British Journal of Politics and International Relations. 20 (3): 693-710.

MacKinnon, D., and J. Shaw, J. 2010. 'New State Spaces, Agency and Scale: Devolution and the Regionalisation of Transport Governance in Scotland”. Antipode, 42 (5): 1226-1252.

Magnussen. W. 2005. "Protecting the Right of Local Self-Government". Canadian Journal of Political Science. 38 (4): 897-922.

Massey, Doreen. 2013. “'Stories so Far’: A Conversation with Doreen Massey”. In Spatial Politics: Essays for Doreen Massey, edited by Featherstone, David, and Joe Painter, 253-266. Oxford: Wiley- Blackwell.

McInroy, N. 2018. “The Everyday Economy: Framing a New Political Economy for the UK?'. The Political Quarterly. 89 (4): 614-617.

Moore, A. 2008. "Rethinking scale as a geographical category: from analysis to practice". Progress in Human Geography. 32 (2): 203-225.

Newman, I. 2014. Reclaiming Local Democracy. Bristol: Policy Press.

Newton, K. 1982. "Is Small Really So Beautiful? Is Big Really So Ugly? Effectiveness and Democracy in Local Government”. Political Studies. 30: 190-206

Nicholls, W.J. 2008. "The Urban Question Revisited: The Importance of Cities for Social Movements". International Journal of Urban and Regional Research. 32 (4):841-859.

O’Neil, M., and T. Howard. 2018. "Beyond extraction: The political power of community wealth building”. Renewal. 26 (2): 46-51. 
Panter-Brick, K. 1954. "Local Self-Government as a Basis for Democracy: A Rejoinder". Public Administration. 32 (4): 438-440.

Pemberton, S. 2016. "Statecraft, scalecraft and local government reorganisation in Wales". Environment and Planning C: Government and Policy. 34 (7): 1306-1323.

Pemberton, S., and M. Goodwin. 2010. "Rethinking the changing structures of rural local government - State power, rural politics and local political strategies?”. Journal of Rural Studies. 26 (3): 272-283.

Pugh, J. 2009. "The Spaces of Democracy and the Democracy of Space: A New Network Exploring the Disciplinary Effects of the Spatial Turn”. Space and Polity. 13 (2): 159-164.

Purcell, M. 2004 “Urban Democracy and the local trap". Urban Studies. 43 (11):1921-1941.

Russell, B. 2019. "Beyond the Local Trap: New Municipalism and the Rise of the Fearless Cities" Antipode. 51 (3): 989-1010.

Seamon, D. "Place Attachment and Phenomenology: The Synergistic Dynamism of Place". In Place Attachment, edited by Manzo, Lynne. C., and Devine-Wright, Patrick, 11-21. London: Routledge.

Sharpe, L. J. 1970. "Theories and Values of Local Government”. Political Studies. 18 (2): $157-8$

Sullivan, H. 2011. "Governing the mix: how local government still matters". In From Recession to Renewal, edited by Jo Richardson, 179-195. Bristol: Policy Press.

Sweeting, D., and C. Copus. 2012. "Whatever happened to local democracy?" Policy \& Politics. 40 (1): 20-37. 
Tomaney, J. 2012. "Parochialism: A defence”. Progress in Human Geography. 37 (5): 658672.

Thrift, N. 2004. "Intensities of Feeling: Towards a Spatial Politics of Affect". Geographiska Annaler: Series B; Human Geography. 86 (1): 57-78.

Willett, J 2016. The Production of Place: Perception, Reality and the Politics of Becoming Political Studies 642 436-451.

Williams, A., M. Goodwin, and P. Cloke. 2014. "Neoliberalism, big society, and progressive localism”. Environment and Planning A .46 (12): 2798-2815.

Wills, J. 2013 "Place and Politics". In Spatial Politics: For Doreen Massey, edited by Featherstone, David, and Joe Painter, 135-145. Chichester: Wiley-Blackwell.

Wills, J. 2016. Locating Localism: Statecraft, citizenship and democracy. Bristol: Policy Press.

Wolman, H. 1996. "Theories of Local Government in the United States". In Rethinking Local Democracy, edited by King, Desmond, and Stoker, G, 158-173. London: MacMillan.

Yorkshire Post. 2018, 26 $6^{\text {th }}$ April. "The County No One Loved" https://www.yorkshirepost.co.uk/news/humberside-the-county-no-one-loved-1-9136027. 